\title{
Thrombolysis in Myocardial Infarction Flow-2
}

National Cancer Institute

\section{Source}

National Cancer Institute. Thrombolysis in Myocardial Infarction Flow-2. NCI Thesaurus.

Code C100042.

Partial reperfusion: The contrast material passes across the obstruction and opacifies the entire coronary bed distal to the obstruction. However, the rate of entry of contrast into the vessel distal to the obstruction and/or its rate of clearance from the distal bed are perceptibly slower than its entry into and/or clearance from comparable areas not perfused by the culprit vessel (e.g., the opposite coronary artery or coronary bed proximal to the obstruction).(www.TIMI.org accessed 21SEP2011) (ACC) 